\title{
Serum levels of chemerin, omentin and vaspin in children with cystic fibrosis
}

\section{Stężenie chemeryny, omentyny i waspiny w surowicy u dzieci z mukowiscydozą}

\section{${ }^{1}$ Edyta Machura, ${ }^{1}$ Katarzyna Ziora, 'Maria Szczepańska, ${ }^{1} E$ Eż̇ieta Świętochowska, ${ }^{1}$ Franciszek Halkiewicz, ${ }^{1}$ Małgorzata Barć-Czarnecka, ${ }^{4}$ Dariusz Ziora}

${ }^{1}$ Department of Pediatrics, School ofMedicine with Division of Dentistry in Zabrze, Medical University of Silesia in Katowice ${ }^{2}$ Department of Medical and Molecular Biology, School ofMedicine with Division of Dentistry in Zabrze, Medical University of Silesia in Katowice ${ }^{3}$ Department of Pneumonology and Tuberculosis,School of Medicine with the Division of Dentistry in Zabrze, Medical University of Silesia in Katowice

\section{Key words}

cystic fibrosis, chemerin, omentin, vaspin, children
${ }^{1}$ Katedra i Klinika Pediatrii, Wydział Lekarski z Oddziałem Lekarsko-Dentystycznym w Zabrzu, Śląski Uniwersytet Medyczny w Katowicach ${ }^{2}$ Katedra Biologii Medycznej i Molekularnej, Wydział Lekarski z Oddziałem Lekarsko-Dentystycznym w Zabrzu, Śląski Uniwersytet Medyczny w Katowicach ${ }^{3}$ Klinika Chorób Płuc,Wydział Lekarski z Oddziałem Lekarsko-Dentystycznym w Zabrzu, Śląski Uniwersytet Medyczny w Katowicach

\section{Słowa kluczowe}

mukowiscydoza, chemeryna, omentyna, waspina, dzieci

\section{Streszczenie}

Wstęp. Pacjenci z mukowiscydozą (cysticfibrosis, CF) prezentują liczne patologiczne stany, jak niedożywienie, zmniejszenie masy tłuszczowej ciała, zaburzenia metaboliczne (zaburzony metabolizm glukozy, wzrost insulinooporności, przewlekły deficyt energii, miejscowe i chroniczne zapalenie), które mogą mieć związek z zaburzeniami stężeń adipokin. Celem badań jest ocena stężenia chemeryny, omentyny i waspiny w surowicy krwi u dzieci z mukowiscydozą. Materiał i metody. Badaniami objęto21 dzieci (średni wiek: 11,7 $\pm 1,59$ lat) ze stabilną CF. Diagnozę CF u tych dzieci potwierdzono badaniem genetycznym. Pacjentów z zaostrzeniem choroby wykluczono z badań. U wszystkich dzieci przeprowadzono wywiad, badanie fizykalne i antropometryczne, zbadano plwocinę, pobrano krew, wykonano czynnościowe badania płuc. Grupę kontrolną stanowiło 22 zdrowych dzieci (średni wiek: 10,9 \pm 4,4 lat). Wyniki. Średnie stężenie chemeryny i omentyny w surowicy krwi było istotnie wyższe $(p<0.001)$, a waspiny znamiennie niższe $(p<0,001)$ u dzieci z mukowiscydozą aniżeli u zdrowych. Nie stwierdzono znamiennych statystycznie korelacji pomiędzy stężeniem badanych adipokin we krwi a BMI, BMI-SDS, glukozą, cholesterolem całkowitym, LDL i HDL we krwi. FEV1 i FVC

Correspondence address / Adres do korespondencji:

Prof. dr hab. n.med. Katarzyna Ziora, Katedra i Klinika Pediatrii Zabrze ul.3 Maja 13/15 41-800, tel.: (32) 3704284 ; tel. kom.: 601 4940 48; fax: (32) 3704 292; ziorkasia@wp.pl 
and glucose, total cholesterol, LDL-, HDL-cholesterol, triglycerides serum levels. FEV1 and FVC correlated positively with BMI - SDS (R:0.58, $p<0.01$; R:0.5, $p<0.036$, respectively). Conclusions. Chemerin and omentin may be involved in the inflammatory process underlying the disease but they do not correlate with disease severity.

Pediatr. Endocrinol. 2017.16.4.61.255-262.

(c) Copyright by PTEiDD 2017

\section{Introduction}

Cystic fibrosis (CF) is an untreatable and lifeshortening inherited autosomal recessive disease with multiorgan manifestation. It is caused by different mutations in a single gene, localized on the long arm of chromosome 7 at position q31.2., which codes Cystic Fibrosis Transmembrane Conductance Regulator (CFTR). CFTR protein is a cAMPactivated chloride channel expressed at the apical membrane on the surface of epithelial cells lining the airways, gastrointestinal tract, cells of exocrine pancreas, airway submucosal and sweat glands [1]. The defective or absent CFTR protein results in poor transport of salt and water into and out of the cells in number of organs. The extent of clinical manifestations is highly heterogeneous in distinct organs. Leading symptoms of typical $\mathrm{CF}$ include increased electrolytes concentration in sweat, exocrine pancreatic insufficiency and progressive pulmonary dysfunction, which is responsible for more than $80 \%$ of CF-related deaths [1]. CF associated bronchopulmonary disease is characterized by multiply alterations including mucostasis, mucus hypersecretion, and chronic neutrophilic inflammation with recurrent bacterial infections, mainly caused by Pseudomonas aeruginosa and Staphylococcus aureus [2,3]. Other CF clinical manifestations comprise chronic rhinosinusitis, hepatic and intestinal disorders, diabetes mellitus, male infertility [1]. Cystic fibrosis is associated with malnutrition, depletion of body fat, but increased percentage of visceral adipose tissue $[4,5]$. Adipokines are protein mediators secreted by the adipose tissue, which were found to be associated with the chronic low-grade inflammation process present in inflammatory diseases and chronic disturbances of metabolism. With related receptors extensively dispersed throughout the body, including the lungs, adipokines may be a contributing factor underlying the complications of CF. We have planned to investigate serum levels pozytywnie korelowało z BMI-SDS (R:0,58, $\mathrm{p}<0,01$; R:0,5; $p<0,036$, odpowiednio). Wnioski. Chemeryna i omentynamogą mieć związek z procesem zapalnym w mukowiscydozie ale nie korelują z ciężkością tej choroby.

Endokrynol. Ped. 2017.16.4.61.255-262.

(c) Copyright by PTEiDD 2017

of selected adipokines such aschemerin, omentin, and vaspinto demonstrate their application as possible markers of inflammation.

Chemerin is a multifunctional protein implicated in chemotaxis of immune cells, regulation of adipogenesis and adipocyte metabolism. Chemerin plays a role in angiogenesis, myogenesis, and glucose homeostasis regulation $[6,7]$.

Chemerin attracts leukocyte populations expressing high affinity functional receptor (ChemR23), particularlyon immature plasmocytoiddendritic cells (DCs), but also immature myeloid DCs, macrophages and natural killer cells. ChemR23 expression was also described in a growing number of non-leukocyte cell populations. These include preadipocytes and adipocytes, osteoclasts, chondrocytes, skeletal muscle and endothelial cells [6].

Chemerin is synthetized as an inactive precursor (prochemerin), which circulates in the bloodstream. Various proteases are able to generate bioactive chemerin from prochemerin including neutrophil serine proteases and proteases from coagulation and fibrinolytic cascades. Prochemerin is expressed at particularly high levels in liver, white adipose tissue and placenta, but is also present in skin, adrenal glands, all parts of the gut, pancreas, the airways, and the kidney [6,7].

Omentin discovered in 2005, a secretory protein of 313 amino acids is an anti-inflammatory adipokine that is abundant in human visceral fat tissue. It is encoded by two genes with omentin-1 being the major circulating form $[8,9]$. Omentin has been reported to exert anti-inflammatory, prosurvival and pro-angiogenic functions in various cells via Akt-dependent mechanism. Higher circulating omentin levels are present in lean and healthy individuals compared with obese and diabetic patients [10].

Vaspin was identified as serpin A12,a member of the serine protease inhibitorsfamily [11] $\mathrm{Hu}$ man vaspin protein consists of 415 amino acids

Serum levels of chemerin, omentin and vaspin in children with cystic fibrosis 
and has $40 \%$ identity with $\alpha-1$ antitripsin [12]. It has been demonstrated that vaspin can play role in insulin resistance and metabolic syndrome, type 2 diabetes mellitus and is involved in vascular inflammation and remodeling [13]. It has been also suggested that an elevated level of vaspin is a compensatory factor in subjects with obesity or insulin resistance [13].

Only a few reports conducted in adult patients with CF focus on the pro-inflammatory role of leptin and anti-inflammatory of adiponectin, which potentially may affect inflammation and glucose tolerance as well as nutritional status in this group $[5,14,15]$. Recently we suggested the role of resistin and apellin in inflammatory processes in children with CF [16]. However, the potential association between CF severity and chemerin, omentin, and vaspinserum levels has not been explored in CF so far, and remains obscure. We have hypothesized, that chemerin, omentin and vaspin also participate in CF pathophysiology and may be associated with the intensity of CF clinical features.

The aim of the study is to evaluate the concentration of chemerin, omentin and vaspin in children with cystic fibrosis.

\section{Material and methods}

The study group,previously described [16], comprised 21 children (aged 4.5-18 years; mean age $11.3 \pm 0.4$ years) with stable CF. The diagnosis of CF was established by sweat test and later confirmed by genetic tests in all subjects. All patients were treated according to European and U.S. guidelines [17]. Patients with pulmonary exacerbation were excluded from this study. In all children the following parameters were assessed: patient history and physical examination, anthropometric parameters, sputum and blood samples, and lung function tests. The control group consisted of 22 healthy children (aged 4-17 years; mean age 10.9 \pm 4.4 years). Children from the control group attended the outpatient pediatric clinic for non - immunological, non inflammatory health problems and needed venous puncture. The present study was approved by Ethics Committee of the Medical University and written informed consent was obtained from children's parents.

Laboratory assays were describedwith details in our previous study [16]. Blood samples for assays were collected in the fasting state between

Edyta Machura, Katarzyna Ziora, Maria Szczepańska, Elżbieta Świętochowska, Franciszek Halkiewicz, Małgorzata Barć-Czarnecka, Dariusz Ziora
8-9.30 am. After centrifugation at 1000x g for 15 min at $4 \mathrm{C}$, the serum samples were frozen at $20 \mathrm{C}$ until analyzed. The absorbance measurements for all samples were performed using the Quant Universal Microplate Spectrophotometer (BioTek Instruments Inc., Winooski, VT, USA) determined on the basis of the standard curve made for a series of dilutions of the standards available in the kit. Acquired data were analyzed using KC Junior Software (v.1.31.5, Bio Tek Instruments, Winooski, VT, USA).

Serum concentrations of chemerin was determined using the immunoenzymatic method with the application of the Human Chemerin ELISA kit (BioVendor, Czech Republic) according to the manufacturer's protocol. The sensitivity of the kit was $0.1 \mathrm{ng} / \mathrm{ml}$. The intra - and inter-assay CV was $6.1 \%$ and $7.5 \%$, respectively. Serum omentinlevel was determined using the immunoenzymatic method with the application of the Human Omentin-1 ELISA kit (BioVendor, Czech Republic) according to the manufacturer's protocol. The sensitivity of the kit was $0,5 \mathrm{ng} / \mathrm{ml}$. The intra - and inter-assay CV was $-3,6 \%$ and 4,6\%, respectively. Serum vaspinconcentration was determined using the immunoenzymatic method with the application of the Human Vaspin ELISA kit (BioVendor, Czech Republic) according to the manufacturer's protocol. The sensitivity of the kit was $0,01 \mathrm{ng} /$ $\mathrm{ml}$. The intra - and inter-assay CV was $-7,6 \%$ and $7,7 \%$ respectively.

All statistical analyses were performed using (MedCalc ver. 12.4.0.0) and $p$ values of $<0.05$ were considered to be significant. To compare the characteristics of the subgroups the MannWhitney Utest was applied. Correlations were analyzed with Spearman tests.

\section{Results}

The characteristics of 20 children with CF and 22 healthy control subjects is presented in table I. Mean values of BMI in CF group were significantly lower than in control group. The mean values of serum levels of chemerin, omentin and vaspinin all children are shown in figures 1-3.

The mean serum levels of chemerin (201.3 $\pm 2.5 \mathrm{ng} / \mathrm{ml})$ and omentin $(41.90 \pm 2,95 \mathrm{ng} / \mathrm{ml})$ were significantly higher than in healthy children $(184.8 \pm 3.2 \mathrm{ng} / \mathrm{ml} ; \mathrm{p}=0.0003$ and $32.09 \pm 3,48 \mathrm{ng} / \mathrm{ml}$; $\mathrm{p}=0.0001$ respectively). The mean values of serum vaspin concentrations were significantly lower in 
Table I. Characteristics of examined children

Tabela I. Charakterystyka badanych dzieci

\begin{tabular}{lccc}
\hline Characteristics & Children with CF $(\mathrm{n}=\mathbf{2 1})$ & Healthy Children $(\mathrm{n}=\mathbf{2 2})$ & $\mathrm{p}$ \\
\hline Age [years] & $11.67 \pm 1.596$ & $10.9 \pm 4.4$ & $\mathrm{~ns}$ \\
Sex [n] & $\mathrm{F}: 11 ; \mathrm{M}: 10$ & $\mathrm{~F}: 12 ; \mathrm{M}: 10$ & $\mathrm{~ns}$ \\
Height [cm] & $144 \pm 9.84$ & $144.9 \pm 21.7$ & 0.02 \\
Weight [kg] & $36.84 \pm 15.7$ & $39.5 \pm 13.0$ & 0.03 \\
BMI [kg/m²] & $17.1 \pm 1.4$ & $18.3 \pm 0.98$ & 0.01 \\
BMI-SDS & $-0.58 \pm-0.71$ & $0.95 \pm 0.82$ & 0.05 \\
\hline CRP [mg\%] & $3.43 \pm 1.77$ & $0.54 \pm 0.17$ & 0.01 \\
BWC & $8.9 \pm 1.42$ & $6.63 \pm 0.85$ & 0.003 \\
Fasting Glucose [mg\%] & $94.43 \pm 4.12$ & $84.36 \pm 2.67$ & $\mathrm{~ns}$ \\
TC [mmol/l] & $3.42 \pm 0.36$ & $3.14 \pm 0.28$ & $\mathrm{~ns}$ \\
LDL [mmol/l] & $1.76 \pm 0.26$ & $1.79 \pm 0.41$ & $\mathrm{~ns}$ \\
HDL [mmol/l] & $1.2 \pm 0.12$ & $1.27 \pm 0.28$ & $\mathrm{~ns}$ \\
TG [mmol/l] & $1.08 \pm 0.23$ & $1.26 \pm 0.77$ & $\mathrm{~ns}$ \\
AspAT [IU/ml] & $32 \pm 0.8$ & $25.41 \pm 4.16$ & 0.001 \\
AIAT[IU/ml] & $33.47 \pm 72$ & $15.88 \pm 3.02$ & 0.0001 \\
\hline FEV1 [\% predicted] & $65.62 \pm 9.73$ & $95.82 \pm 1.7$ & 0.0001 \\
FVC [\% predicted] & $67.11 \pm 8.6$ & $94.11 \pm 2.8$ & 0.0001 \\
FEV1/FVC [\%] & $78.87 \pm 6.28$ & $90.03 \pm 1.5$ & \\
\hline
\end{tabular}

Data are shown as mean \pm SE; BMI - body mass index; BMI-SDS - body mass index standard deviation score; CRP - C-reactive protein; HDL-C - high-density lipoprotein cholesterol; IU - international unit; LDL-C - low-density lipoprotein cholesterol; SE - standard error; TC - total cholesterol; TG - triglyceride; FEV $_{1}$ - forced expiratory volume in 1 second; FVC - forced vital capacity

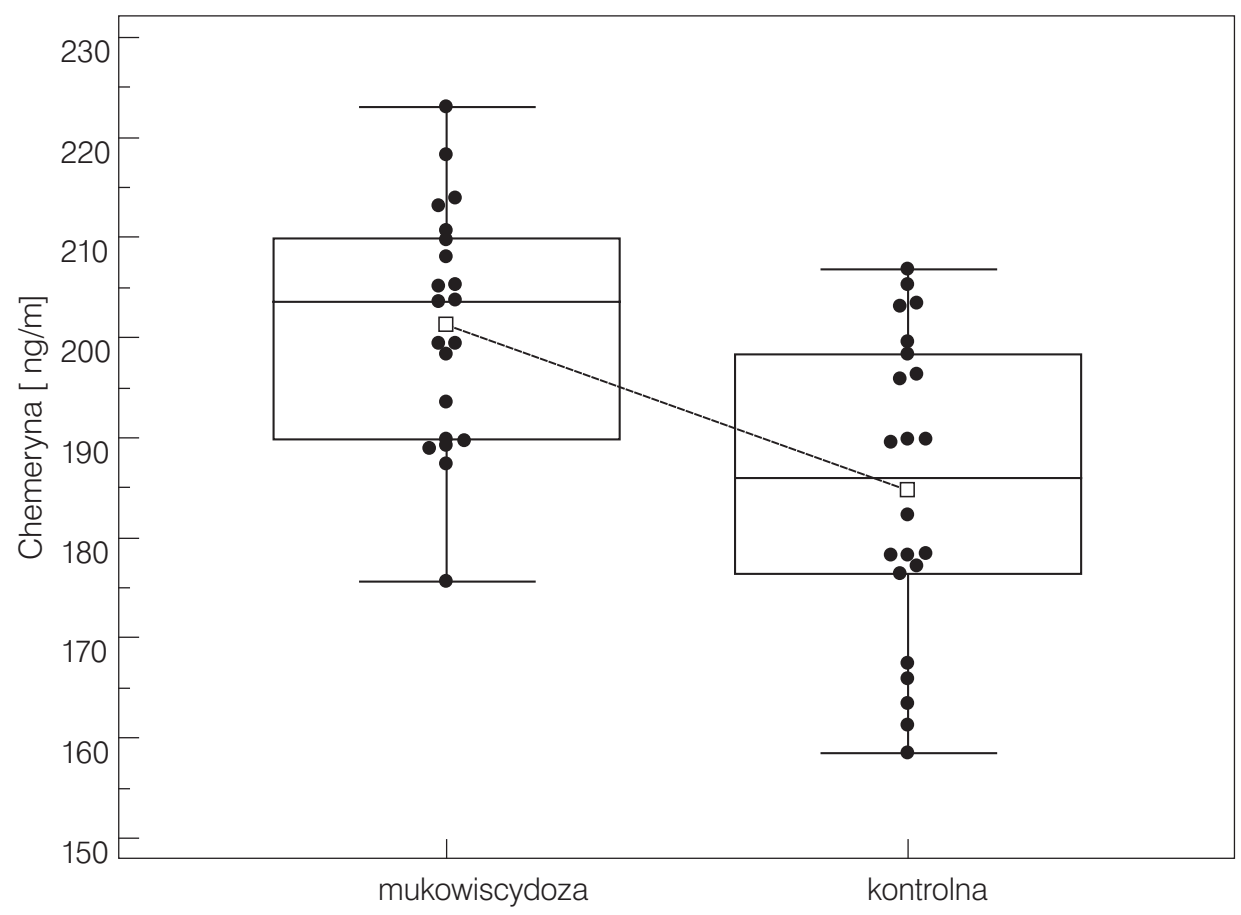

Fig. 1. Serum level of chemerin in children with cystic fibrosis and control group

Ryc. 1. Stężenie chemeryny w surowicy krwi u dzieci z mukowiscydozą i w grupie kontrolnej 


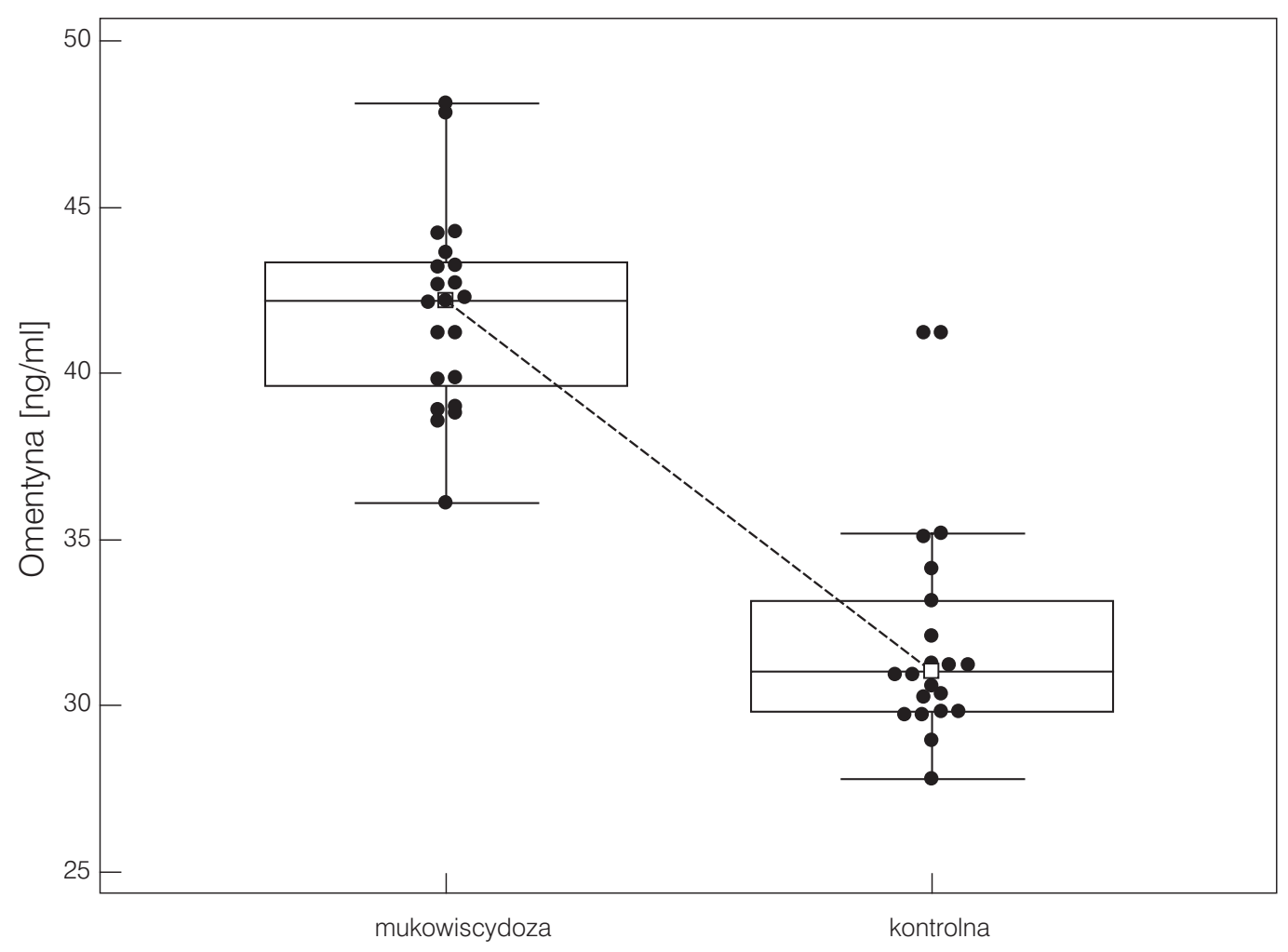

Fig. 2. Serum level of omentin in children with cystic fibrosis and control group

Ryc. 2. Stężenie omentyny w surowicy krwi u dzieci z mukowiscydozą i w grupie kontrolnej

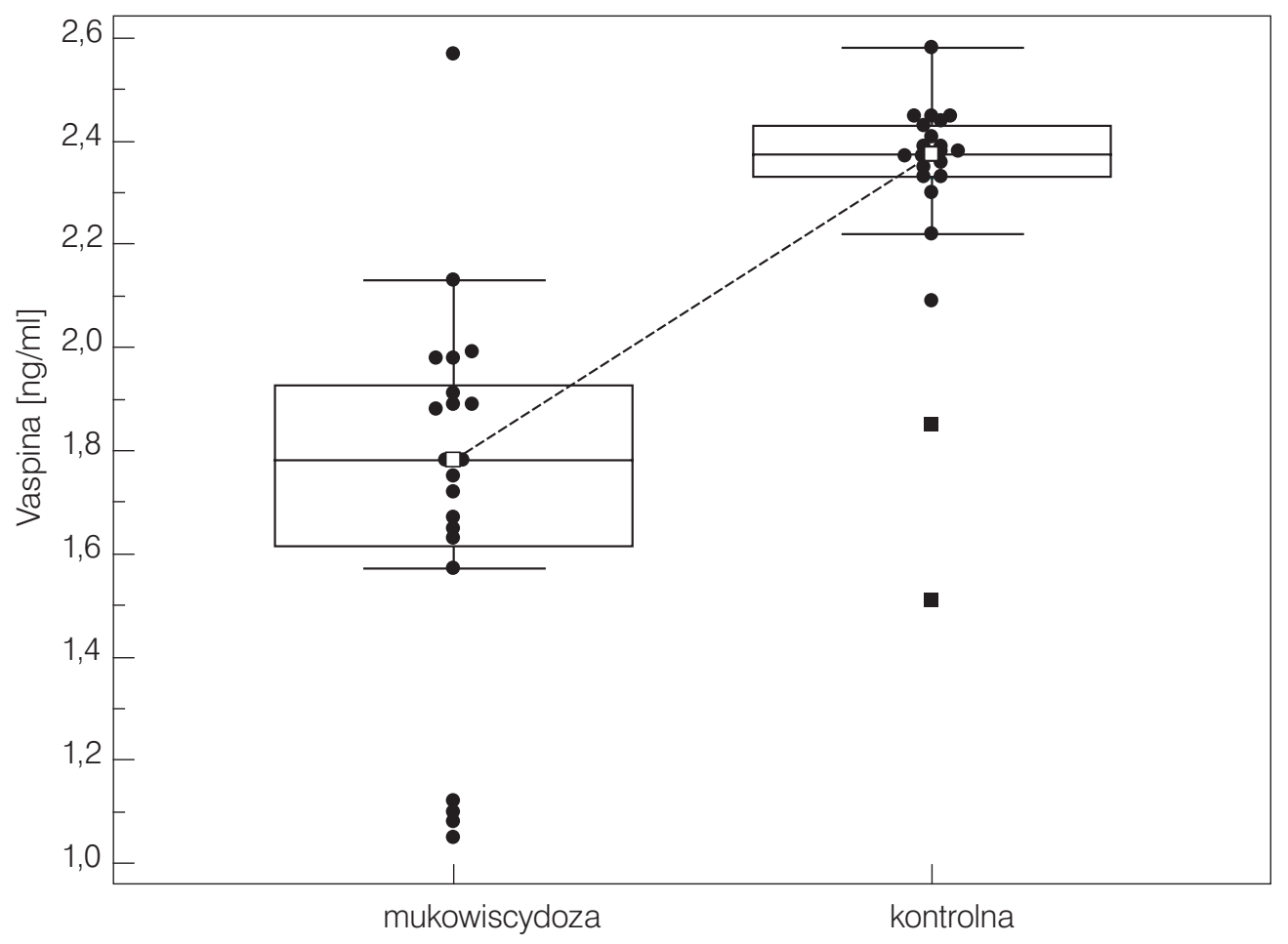

Fig. 3. Serum level of vaspinin children with cystic fibrosis and control group

Ryc. 3. Stężenie waspiny w surowicy krwi u dzieci z mukowiscydozą i w grupie kontrolnej 
CF children $(1.72 \pm 0,38 \mathrm{ng} / \mathrm{ml})$ than in healthy children (2.31 $\pm 0,23 \mathrm{ng} / \mathrm{ml} ; \mathrm{p}=0.001)$.

Age of $\mathrm{CF}$ patients correlated positively with chemerin levels ( $r=0.43 ; \mathrm{p}<0.042)$. BMI of CF children correlated with TG (R: 0,8; $\mathrm{p}<0.0001)$ and CRP levels (R:0.52; p<0.0017). CRP correlated with chemerin levels (R: 0.45; $\mathrm{p}<0.042$ ). Concentrations of examined adipokines showed no correlation with BMI, BMI-SDS, glucose, total and LDL, HDL cholesterol, triglyceride serum levels orspirometric parameters such as FEV1, FVC, FEV1/FVC.

\section{Discussion}

CF patients present numerous conditions such as malnutrition and depletion of fat free mass, metabolic disturbances including abnormal glucose metabolism, increased insulin resistance, chronic energy deficit, local and chronic inflammation, all of which could affect or be associated with altered adipokines concentration [1-4]. In this study we observed a significant increase in serum levels of chemerin and omentin, but decrease in serum levels of vaspinas compared to healthy subject.

Major characteristicsof CF airways is a state of chronic inflammation. The CF airways contain several proinflammatory mediators including TNF- $\alpha$, IL-1 $\beta$, IL-6, IL-8, MIF $[2,3]$. We observed a strong positive correlation between chemerin and CRP levels. The secretion of chemerin is efficiently induced by pro-inflammatory cytokines, including TNF- $\alpha$, IL-1 $\beta$ and by cysteine protease (Staphopain B), secreted by pathogens such as Staphylococcus aureus, which are increased in CF patients [2,3].

In human plasma chemerin levels were higher in many chronic inflammatory disorders including rheumatoid arthritis, coronary artery disease, obesity, type 2 diabetes, Crohn disease or COPD (chronic obstructive pulmonary disease) [18-21]. Additionally increased expression of chemerin was found in various inflammatory sites including skin lesion of acute psoriasis, lupus and in kidney tissuein lupus nephritis [18-21]. In contrast, lower chemerin levels were found in children with anorexia nervosa [22]. Interestingly, in animal model, both pro-inflammatory and anti-inflammatory roles of chemerin have been reported. Chemerin suppresses murine allergic asthma, and exerts anti-inflammatory activities in experimental peritonitis and lung injury [23,24]. Chemerin is predicted to share similar tertiary structure with antibacterial cathelicidins and is implicated in inhibition ofbacteria growth [25]. In several studies was shown that chemerin correlated with BMI, fasting glucose, fasting insulin, cholesterol, TG, and inflammatory markersincluding CRPlevels $[20,21]$.

Also serum omentin was higher in CF children as compared to healthy ones. Omentin can inhibit inflammation via several signaling pathways. It suppresses CRP and TNF- $\alpha$ synthesis, $\mathrm{NF}-\kappa \mathrm{B}$ induced ICAM-1, VCAM-1 expression, and increaseseNOs. Thereforeomentin has ananti - inflammatory effect on smooth muscle cells and endothelium [25]. Omentin protects against pulmonary arterial hypertension through vascular structure remodeling and abnormal contractile reactivity inhibition [26]. Moreover omentin protects against LPS-induced acute respiratory distress (ARDS) suppressing pulmonary inflammation and promoting endothelial barrier stabilization [27].

On the other hand the reduced omentin levels are related with atherosclerosis, hypertension, cardiovascular disease and obstructive sleep apnea $[26,28]$. Omentin is inversely correlated with BMI, insulin resistance and positively with HDL and adiponectin [29]. If omentinthrough the increase of insulin sensitivity and protective effect on the lung injury may be a "good adipokine" in CT patients remains to be elucidated.

The serum vaspin levels were decreased in CF children like in ischemic heart disease and girlswith anorexia nervosa [30-32]. Decreased serum vaspin concentrations may simply reflect reduced fat mass in CF like in obese subjects after 12-weeks short term weight reduction program [33]. Interestingly thevaspin levels in sera were elevated in rheumatoid arthritis and obstructive sleep apneahypopnea syndrome [34,35].

The beneficial effect of vaspin on vascular cells was shown in several studies. It was demonstrated that vaspin exerted antiatherogenic effect on vascular cells and significantly decreased $\mathrm{TNF} \alpha-$ induced activation of $\mathrm{NF}-\kappa \mathrm{B}$, as well as the expression of the adhesion molecules ICAM-1, VCAM-1, E-selectin, and MCP-1 [35].

In this study any correlation between examined adipokines and BMI and BMI-SDS, glucose, total and LDL, HDL cholesterol, triglyceride serum levels and spirometric parameters such as $\mathrm{FEV}_{1}$, FVC, $\mathrm{FEV}_{1} / \mathrm{FVC}$ were found.

In conclusion, a significant increase of chemerin and omentin serum levels accompanied by the

Serum levels of chemerin, omentin and vaspin in children with cystic fibrosis 
decrease in serum levelofvaspinobserved in children with CF may suggests that these adipokines are involved in the inflammatory process underlying the disease like resistin and apellin12 described in our previous study [16]. However chemerin and omentin seem not to be associated with the severity of CF and clinical features. To the best our knowledge the role of these adipokines $\mathrm{CF}$ has not yet been investigated in patients with CF so is impossible to directly compare our results with others.
Although this was a cross-sectional study with a relatively small sample size we believe that our data may be a starting pointfor further studies evaluating the possible role of adipokines in $\mathrm{CF}$ pathogenesis.

\section{Acknowledgments}

This study was supported by grant no KNW-1$132 / \mathrm{k} / 5 / 0$ from the State Committee for Research in Poland

\section{References / Piśmiennictwo}

1. De Boeck K., Wilschanski M., Castellani C. et al.: Cystic fibrosis: terminology and diagnostic algorithms. Thorax, 2006:61,627-635

2. Sagel S.D., Wagner B.D., Anthony M.M. et al.: Sputum biomarkers of inflammation and lung function decline in children with cystic fibrosis. Am.J.Respir. Crit. Care Med., 2012:186,857 - 865.

3. Cohen-Cymberknoh M., Kerem E., FerkolT. et al.: Airway inflammation in cystic fibrosis: molecular mechanisms and clinical implications. Thorax 2013:68, 1157-1162.

4. Dhaliwal J., Leach S., Katz T. et al.:Intestinal inflammation and impact on growth in children with cystic fibrosis. J.Pediatr.Gastroenterol.Nutr., 2015: 60, 521-526.

5. Moriconi N., Kraenzlin M., Müller B. et al.: Body composition and adiponectin serum concentrations in adult patients with cystic fibrosis. J.Clin.Endocrinol. Metab., 2006:91(4), 1586-1990.

6. Bondue B., Wittamer V., Parmentier $\mathrm{M}$. :Chemerin and its receptors in leukocyte trafficking, inflammation and metabolism. Cytokine Growth. Factor. Rev., 2011:22 (5-6), 331.

7. Fatima S.S., Rehman R., Baig M. et al.: New roles of the multidimensional adipokine: chemerin. Peptides., 2014:62, 15-20.

8. Ouchi N, ParkerJ.L., Jesse J.,Lugus J.L. et al.:Adipokines in inflammation and metabolic disease. Nat.Rev.Immunol., 2011:11(2), 85-97.

9. Szydło B., Kiczmer P., Świętochowska E., Ostrowska Z.: Role of omentin and chemerin in metabolic syndrome and tumor diseases. Postępy Hig .Med. Dosw. (Online), 2016:70, 844-849.

10. Jaikanth C., Gurumurthy P., Cherian K.M. et al.: Emergence of omentin as a pleiotropic adipocytokine. Exp. Clin. Endocrinol. Diabetes, 2013:121(7), 377-383.

Edyta Machura, Katarzyna Ziora, Maria Szczepańska, Elżbieta Świętochowska, Franciszek Halkiewicz, Małgorzata Barć-Czarnecka, Dariusz Ziora
11. Silverman G.A., Bird P.I., Carrell R.W. et al.: The serpins are an expanding superfamily of structurally similar but functionally diverse proteins. Evolution, mechanism of inhibition, novel functions, and a revised nomenclature. J. Biol. Chem., 2001:276, 33293-33296.

12. Hida K., Wada J., Eguchi J., Zhang H. et al.: Visceral adipose tissue-derived serine protease inhibitor: a unique insulin-sensitizing adipocytokine in obesity. Proc. Natl. Acad. Sci. USA, 2005:102,10610-10615.

13. Blüher M.: Vaspin in obesity and diabetes: pathophysiological and clinical significance. Endocrine., 2012:41(2), 176-182.

14. Ziai S., Belson L., Malet A. et al.: The association between leptin and insulin levels in adults with cystic fibrosis. Diabetes. Metab., 2012:38, 34-39.

15. Cohen R.I., Tsang D., Koenig S. et al.: Plasma ghrelin and leptin in adult cystic fibrosis patients. J. Cyst. Fibros., 2008:7, 398-402.

16. Machura E., Szczepańska M., Świętochowska E. et al.: Evaluation of adipokines in children with cystic fibrosis. Endocrinol. Pol. 2017 in press.

17. Smyth A.R., Bell S.C., Bojcin S. et al.: European Cystic Fibrosis Society Standards of Care: Best Practice guidelines. J. Cyst. Fibros., 2014: 13 (Suppl 1), S23-S42.

18. Rourke J.L., Dranse H.J., Sinal C.J.: Towards an integrative approach to understanding the role of chemerin in human health and disease. Obes. Rev., 2013:14(3), 245-262

19. Hamza R.T., Elkabbany Z.A., Shedid A.M. et al.: Serum chemerin in obese children and adolescents before and after L-Carnitine therapy: Relation to nonalcoholic fatty liver disease and other features of metabolic syndrome. Arch. Med. Res., 2016: 47(7), 541-549.
20. Zylla S., Pietzner M., Kühn J.P. et al.: Serum chemerin is associated with inflammatory and metabolic parameters-results of a population-based study. Obesity., 2017:25(2), 468-475.

21. Boyuk B., Guzel E.C., Atalay H. et al.: Relationship between plasma chemerin levels and disease severity in COPD patients. Clin. Respir. J., 2015:9(4), 468-474.

22. Oświęcimska J.M., Ziora K.T., Suwała A. et al.:Chemerin serum levels in girls with anorexia nervosa. Neur. Endocrinol. Lett., 2014:35(6), 490-496.

23. Mariani F., Roncucci L.: Chemerin/ chemR23 axis in inflammation onset and resolution. Inflamm. Res., 2015:64 (2), 85-95

24. Zhao L., Yang W., Yang et al.: Chemerin suppresses murine allergic asthma by inhibiting CCL2 production and subsequent airway recruitment of inflammatory dendritic cells. Allergy., 2014:69(6), 763-774

25. Wang C.: Obesity, inflammation, and lung injury (OILI): the good. Mediators. Inflamm., 2014:2014:978463. Doi: 10.1155/2014/978463. Epubl 2014 May 11. Review.

26. Mattu H.S., Randeva H.S.: Role of adipokines in cardiovascular disease. J. Endocrinol., 2013:216(1), T17-36.

27. Qi D., Tang X., He J. et al.: Omentin protects against LPS-induced ARDS through suppressing pulmonary inflammation and promoting endothelial barrier via an Akt/eNOS-dependent mechanism. Cell Death. Dis., 2016:7(9), e2360.

28. Uygur F., Tanriverdi H., Can M. et al.: Association between continuous positive airway pressure and circulating omentin levels in patients with obstructive sleep apnoea. Sleep. Breath., 2016:20(3), 939-945.

29. Jaikanth C., Gurumurthy P., Cherian K.M. et al.: Emergence of omentin as 
a pleiotropic adipocytokine. Exp. Clin. Endocrinol. Diabetes, 2013:121 (7), 377-383.

30. Blüher M.:Vaspin in obesity and diabetes: pathophysiological and clinical significance. Endocrine, 2012:41 (2), 176-182.

31. Oświęcimska J., Suwała A., Świętochowska E. et al.: Serum vaspin concentrations in girls with anorexia ne- rvosa. J. Pediatr. Endocrinol. Metab. 2016:29(6), 681-686.

32. Salama H.M., Galal A., Motawie A.A et al.: Adipokinesvaspin and visfatin in obese children. Open Access Maced. J. Med. Sci., 2015:3 (4), 563-566.

33. Chang H.M., Lee H.J., Park H.S. et al.: Effects of weight reduction on serum vaspin concentrations in obese sub- jects:modification by insulin resistance. Obesity., 2010:18,2105-2110.

34. Pan Z., Zhuang X., Li X. et al.: Significance of vaspin in obstructive sleep apnea-hypopnea syndrome. Exp. Ther. Med., 2016:11 (3), 841-845.

35. Heiker J.T.: Vaspin (serpinA12) in obesity, insulin resistance, and inflammation. J. Pept. Sci., 2014:20 (5), 299306. 